\author{
OAK RIDGE \\ NATIONAL LABORATORY \\ MANAGED BY UT-BATTELLE \\ FOR THE DEPARTMENT OF ENERGY
}

C/ORNL95-0351

Metals and Ceramics Division

CRADA Final Report

for

CRADA Number ORNL95-0351

Optimization of Pseudo-

Porous SiC Fiber Coatings for SiC/SiC Composites

Edgar Lara-Curzio and K. L. Moref.

Oak Ridge National Laboratory

R. Shinavski

Hyper-Therm High Temperature

Composites, Inc.

Date Published - October 2000

Prepared by the OAK RIDGE NATIONAL

LABORATORY

Oak Ridge, Tennessee 37831

Managed by

UT-BATTELLE, LLC

for the

U.S. DEPARTMENT OF ENERGY

under contract DE-AC05-00OR22725

APPROVED FOR PUBLIC

RELEASE

UNLIMITED DISTRIBUTION

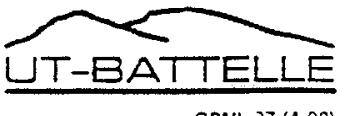

ORNL.2T (4.00) 
C/ORNL95-0351

Metals and Ceramics Division

CRADA Final Report

for

CRADA Number ORNL95-0351

\section{Optimization of Pseudo-Porous SiC Fiber Coatings for SiC/SiC Composites $^{1}$}

Edgar Lara-Curzio and K. L. More

Oak Ridge National Laboratory

R. Shinavski

Hyper-Therm High Temperature Composites, Inc.

Date Published - October 2000

Prepared by the

OAK RIDGE NATIONAL LABORATORY

Oak Ridge, Tennessee 37831

Managed by

UT-BATTELLE

for the

U.S. DEPARTMENT OF ENERGY

under contract DE-AC05-00OR22725

\section{APPROVED FOR PUBLIC RELEASE UNLIMITED DISTRIBUTION}

\footnotetext{
' This work was supported through a CRADA with Hyper-Therm High-Temperature Composites. Inc., sponsored by the CFCC Program, Office of Industrial Technologies, U.S. Department of Energy, started under contract DE-AC05-96OR22464 with Oak Ridge National Laboratory, managed by Lockheed Martin Energy Research Corporation, and completed under contract DE-AC05-00OR22725, managed by UT. Battelle, LLC..
} 


\section{Abstract}

The objective of this Cooperative Research and Development Agreement between Lockheed Martin Energy Research Corporation and Hyper-Therm High-Temperature Composites, Inc. was the optimization of the microstructure of pseudo-porous $\mathrm{SiC}$ fiber coatings for $\mathrm{SiC} / \mathrm{SiC}$ composites. Extensive interfacial test characterization was conducted through single-fiber push-out tests and analytical electron microscopy to assess the effect of various microstructural features of the fiber coating on the interfacial properties of the composite. The thermal stability of these coatings and their interfaces was also investigated after exposure to air at elevated temperatures.

\section{Objectives}

The technical objective of the CRADA was:

- to identify the microstructural features of pseudo-porous $\mathrm{SiC}$ fiber coatings that provide conditions for fiber debonding and sliding in the wake of matrix cracks, particularly at elevated temperatures and provide guidance for the optimization of the microstructure of these coatings.

\section{Meeting Objectives}

All tasks were completed.

\section{CRADA Benefit to DOE}

The results from this study helped to develop an understanding of the role of various microstructural features of pseudo-porous fiber coatings on its functionality in ceramic matrix composites. This understanding has helped to provide insights in the development of a new generation of materials capable of meeting the very demanding conditions and requirements associated with the energy industries in the U.S. 


\section{Technical Discussion}

Introduction

Continuous fiber-reinforced ceramic matrix composites (CFCCs) constitute a relatively new class of materials with the potential for retaining strength and exhibiting tough behavior at elevated temperatures. The development of CFCCs has been driven to a great extent by the promise of substantial environmental and economic benefits if these materials are used in high-temperature industrial applications, particularly in the energyrelated industries. The main attributes that make these materials attractive for these applications are their low density, their corrosion and wear resistance, and the potential for exhibiting dimensional stability and retention of strength at elevated temperatures. Most of the potential applications for these materials involve aggressive environments. For example, these materials are being considered for the fabrication of filters in coalfired power plants that would be subjected to both oxidizing and reducing environments at elevated temperatures. These materials are also being considered for the manufacture of combustor liners for gas turbine engines. In this application stresses arise from thermal gradients through the wall of the component but the most severe conditions arise from being subjected to large heat fluxes, elevated temperature, and high pressure combustion environments. In most of these applications, these components are expected to last for tens of thousands of hours.

In general, the strength and toughness of CFCCs are controlled by the reinforcing fibers and by the fiber coatings. The roles of the fiber coating are: to allow for fiber debonding and fiber sliding in the wake of advancing cracks in the matrix; to protect the fibers during the synthesis of the matrix and from the service environment when this can ingress to the interior of the composite through matrix cracks. 


\section{Experimental}

Single-fiber interfacial tests were conducted on materials densified by Hyper-Therm High Temperature Composites, Inc. Materials were synthesized with pseudo-porous SiC fiber coatings having various microstructures. The results from the single-fiber interfacial tests provide quantitative and qualitative information on the ability of fiber coatings and their interfaces to deflect cracks in the matrix. These results were complemented with transmission electron microscopy and other analytical techniques to determine the microstructure of the material and its changes after exposure to air at elevated temperatures.

\section{Conclusions}

The relationship between the microstructural features of pseudo-porous $\mathrm{SiC}$ fiber coatings and their ability to deflect cracks at the fiber/matrix interface of $\mathrm{SiC} / \mathrm{SiC}$ composites was investigated. The ability of these fiber coatings to meet their functional requirements when $\mathrm{SiC} / \mathrm{SiC}$ composites are exposed to air at elevated temperatures was determined.

\section{Report of Inventions}

There were no inventions developed under this agreement.

\section{Commercialization Possibilities}

Hyper-Therm High-Temperature Composites Inc., is offering variations of the materials investigated in this project on a commercial basis.

\section{Plans for Future Collaborations}

Informal collaborations are maintained between the parties. but no plans have been made for future formal collaborations. 


\section{INTERNAL DISTRIBUTION}

1. R. A. Bradley, 4500S, 6061

2. M. A. Karnitz, 4515,6065

3. E. Lara-Curzio, 4515,6069

4. K. L. More, 4515,6064

5. C. A. Valentine, $111 \mathrm{UNV}, 6429$

6. Dave Hamrin, $4500 \mathrm{~N}, 6285$

7-8 Lab Records, 4500N, 6285

\section{EXTERNAL DISTRIBUTION}

1. Deborah Haught, Program Manager, Office of Power Technologies, DOE, Washington, DC 20585, DOE

2. P. A. Carpenter, DOE-ORO, ORNL Site Office, P. O. Box 2008, Oak Ridge, Tennessee 37831-6269

3. M. H. Rawlins, Program Manager, DOE-ORO, Oak Ridge, TN 37831-6269

4. R. Shinavski, Hyper-Therm, High Temperature Composites, 18411 Gothard St, Units B\&C, Huntington Beach, CA 92648

5. Merrill Smith, Program Manager, Combiend Heat and Power, Office of Power Technologies, U. S. Department of Energy, Washington, DC 20585

6-7. Office of Scientific and Technical Information, P. O. Box 62, Oak Ridge, Tennessee 37831

8. DOE-WFO, MS G209 


\section{Hyper-Therm, Inc. \\ High-Temperature Composites}

18411 Gothard Street, Units B \& C

Huntington Beach, CA 92648

Tel: (714) 375-4085

Fax: (714) 375-4087

E-mail:wsteffier@htcomposites.com

September 22, 2000

Edgar Lara-Curzio

Oak Ridge National Laboratory

Bldg. 4515/MS 6069

PO Box 2008

Oak Ridge, TN 37831-6069

Letter No. 000922-01

Subject: Approval for public release CRADA final report for CRADA ORNL 95-0351

Dear Edgar:

Hyper-Therm, Inc. High Temperature Composites (Hyper-Therm) has reviewed the subject document, and finds no information that is considered the proprietary data of Hyper-Therm.

Please continue to consider Hyper-Therm for any of your needs in fiber coatings or ceramic matrix composites.

Thank you for your patience in this matter.

Sincerely,

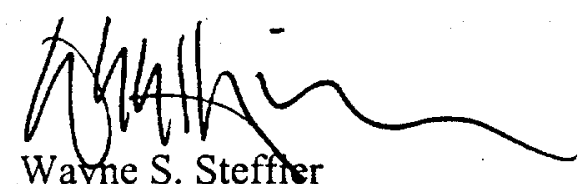

Wayne S. Steffter

President 